\title{
WĄTKI FILOZOFICZNE W DRAMATACH KAROLA WOJTYŁY
}

W artykule pragnę z dramatów Brat naszego Boga, Przed sklepem jubilera i Promieniowanie ojcostwa wydobyć wątki, które były również w polu badawczego zainteresowania w myśli filozoficznej Karola Wojtyły. Prof. Tadeusz Styczeń SDS, następca w Katedrze Etyki KUL po wyborze Karola Wojtyły na Stolicę Piotrową, jego bliski współpracownik i twórczy kontynuator, a także założyciel i długoletni dyrektor Instytutu Jana Pawła II KUL, niejednokrotnie mówił' ${ }^{1}$ że to, co zajmowało intelektualnie Wojtyłę, znajdowało swój wyraz w różnych formach wypowiedzi, tak filozoficznych, teologicznych, jak i literackich, że wypowiadał się on na te same tematy za pomocą ,różnych języków”. Na podobnych przesłankach oparł się również Giovanni Reale, który wyraził przekonanie, że aby owocnie badać pewną część dzieł Wojtyły, nie należy tracić z oczu ich całości, na którą składają się twórczość filozoficzna, teologiczna i literacka, ponieważ był on w równym stopniu filozofem, teologiem i poetą (11-12, 27-29). Można zatem całkowicie zasadnie uznać, że za analizą tekstów należących do różnych obszarów twórczości Wojtyły - w naszym przypadku myśli filozoficznej i twórczości dramaturgicznej - przemawia to, że „oświetlają” one te same tematy czy problemy z odmiennych perspektyw. Zwracał na to uwagę ks. Alfred M. Wierzbicki, twierdząc, że prace filozoficzne, teologiczne i literackie Wojtyły charakteryzuje „wzajemna osmoza i przenikanie” (103).

Karol Wojtyła nazywany jest filozofem osoby. Miano to jest w pełni uzasadnione, ponieważ jego namysł filozoficzny dotyczył człowieka jako osoby, zarówno w jego

Dr Tomasz GóRKa - Instytut Jana Pawła II KUL; adres do korespondencji: Katolicki Uniwersytet Lubelski Jana Pawła II, Al. Racławickie 14, 20-950 Lublin; e-mail: tomaszg@kul.lublin.pl. ORCID: http://orcid.org/0000-0002-4743-9585.

${ }^{1}$ Podczas formalnych i prywatnych rozmów z udziałem osób związanych z Instytutem, których autor artykułu był świadkiem. 
bycie i podmiotowości (dostępnej przez doświadczenie i przeżycie), jak i jego relacji z innymi osobami. Opierając się na idei imago Dei (podobieństwa do Boga), rozwijał swoją filozofię człowieka jako bytu osobowego, a więc obdarzonego rozumem, wolnego, posiadającego własną konstytucję cielesną, a także wyjątkową wartość, jaką jest godność osobowa. Ważna część jego myśli filozoficznej poświęcona jest relacjom międzyosobowym i zdolności człowieka do wchodzenia i tworzenia różnych wspólnot na zasadzie communio personarum (jak również zaprzeczeniu tej zdolności przyjmującemu formę alienacji), a przede wszystkim opartemu na normie personalistycznej fenomenowi miłości ludzkiej, która swoją pełnię osiąga w miłości oblubieńczej, rozumianej jako bezinteresowny, całkowity i wolny dar osoby dla osoby. W powiązaniu z miłością i wartością, jaką stanowi godność, badał także odpowiedzialność człowieka za własne czyny, jak i za drugą osobę. Znaczną część jego filozofii stanowiły też badania nad sumieniem i nad powinnością moralną, a także nad spełnieniem się człowieka jako osoby w horyzoncie celu ostatecznego, którym jest Bóg (Osoba i czyn, Miłość i odpowiedzialność, „O miłości oblubieńczej (Na marginesie dyskusji)”, „Rodzina jako communio personarum. Próba interpretacji teologicznej” i „Rodzicielstwo a communio personarum”).

Jak z powyższego wynika, zainteresowania i prowadzone badania filozoficzne Karola Wojtyły były szerokie i różnorodne. $Z$ tego powodu, a także ze względu na ograniczone ramy tego artykułu, zajmę się wskazaniem i omówieniem tylko niektórych wątków filozoficznych zawartych w dramatach Karola Wojtyły. Swojej analizy dokonam z zachowaniem chronologii powstawania utworów.

\section{DRAMAT BRAT NASZEGO BOGA I ZALĄŻKI BADAŃ FILOZOFICZNYCH KAROLA WOJTYŁY}

Przystępując do analizy najwcześniej napisanego dramatu Karola Wojtyły, który powstał niedługo po zakończeniu II wojny światowej - Brat naszego Boga, możemy przywołać przytoczoną przez Krzysztofa Dybciaka opinię Marka Skwarnickiego, że w dramacie tym znajdują się zaczątki wszystkiego, co późniejszy papież Jan Paweł II mówi na temat kwestii społecznych (Dybciak, ,Rewolucja czy wybór większej wolności?" 51). Jednak jesteśmy przekonani, że - rozszerzając zakres tej opinii - Brat naszego Boga zawiera zalążki i elementy zagadnień filozofii osoby, które Wojtyła podejmował w swoich późniejszych pracach naukowych.

Panuje dość powszechne przekonanie, że Brat naszego Boga to utwór dotyczący głównie kwestii społecznych i politycznych (Dybciak 43, 48), jednak trudno się całkowicie z tym zgodzić. Oczywiście dramat porusza kwestie nędzy i niesprawiedliwości społecznej, która budzi słuszny gniew pokrzywdzonych oraz prowadzi 
do napięć społecznych, jak również ważny jest wątek budzącej się świadomości mas robotniczych oraz nadchodzącej rewolucji, której rzecznikiem jest w dramacie Nieznajomy. Jednak wszystko to - w naszym przekonaniu - stanowi jedynie tło tego dramatu. Warunki zewnętrzne nie są determinujące, chociaż stanowią ważny element w życiu każdego człowieka, ponieważ wobec otaczającej rzeczywistości każdy musi zająć jakąś postawę, musi dokonać wyboru drogi życiowej. Dlatego należy stwierdzić, że zasadniczym tematem dramatu jest indywidualne dojrzewanie wewnętrzne, budzenie się do pełni człowieczeństwa oraz spełnienie się osoby poprzez wybór drogi życiowej (powołania) (Kaczmarek, „Przeniknąć człowieka” 482). Najważniejszy jest człowiek oraz jego osobowe spełnienie w horyzoncie celu ostatecznego, jakim jest Bóg.

Z uwagi na to należy stwierdzić, że niewątpliwie pierwszy wątek filozoficzny stanowi sam człowiek w całym bogactwie jego życia. Głównym bowiem przedmiotem zainteresowania i badań filozoficznych Karola Wojtyły jest człowiek jako osoba. Osoba - jak mówiliśmy o tym we wstępie - w jej wielorakim dynamizmie, jej rozwój, wchodzenie w różnorakie relacje z innymi osobami, a także spełnienie się osoby, zwłaszcza w wymiarze moralnym, przybierającym postać świętości².

Metodą badania i zasadniczym źródłem wiedzy o człowieku w filozofii Wojtyły jest doświadczenie. Dzięki niemu uzyskujemy poznanie nie tylko otaczającej nas rzeczywistości, ale również nas samych. W tym horyzoncie można zatem odczytać pierwsze zdanie ze „Wstępu” do dramatu, zawierające deklarację Autora, że jego utwór stanowi próbę przeniknięcia człowieka (Brat naszego Boga 109), a także słowa Adama w piątej scenie drugiego aktu, gdy widzi, że jego dotychczasowe działania nie dotykają tego, co najważniejsze: „Bo tu chodzi o człowieka” (151).

Drugi obecny w omawianym dramacie wątek filozoficzny - chociaż literalnie mowa o nim w ostatnim zdaniu utworu - to wolność człowieka. Dramat Wojtyły opowiada historię wolności, dzieje samostanowienia Adama - zdobywania samego siebie i kierowania się poznaną prawdą. Możliwe są różne sposoby realizowania wolności, ale chodzi o to, aby wybrać ten właściwy i najlepszy dla człowieka, o czym na końcu dramatu mówi Brat Albert: „Wiem jednak na pewno, że wybrałem większą wolność" (182).

Właściwe rozpoznanie dobra i hierarchii dóbr, czyli poznanie prawdy o dobru, rodzi powinność działania. Adam poznaje nie tylko nędzę ludzi zamieszkujących ogrzewalnię miejską, ale również doświadcza, że są oni takimi samymi ludźmi jak on, że posiadają tę samą godność, która wypływa z faktu stworzenia przez Boga

\footnotetext{
${ }^{2} \mathrm{O}$ takim wymiarze świętości pisała m.in. Dorota Heck (Heck 221).

${ }^{3}$ Należy również pamiętać o najważniejszym doświadczeniu Adama, które zaważyło na jego dalszym życiu i od którego wszystko się zaczęło, czyli od wizyty w ogrzewalni miejskiej.
} 
wszystkich ludzi, a potwierdzona została przez ofiarę Jezusa na krzyżu. Dlatego kolejnym ważnym motywem dramatu, właśnie ze względu na afirmację godności osób ubogich pod względem materialnym, jest miłość. Autor dramatu wprost nie powołuje się na normę personalistyczną, ani nie posługuje się teoretyczną kategorią godności, jednak to one są centralnym, choć nie nazwanym wyraźnie motywem tego utworu. Adam poruszony jest nie tylko biedą bezdomnych, ale również dostrzega w nich ludzi, których należy kochać (145; Taborski, Dramaturgia wnętrza 57)4 Najpierw podejmuje działania charytatywne, a następnie decyzję o staniu się jednym z nich, ponieważ ludzie ci stanowią dla niego cel działania (Kaczmarek, „Od doświadczenia człowieka do miłości osoby” 356).

Kolejnym wątkiem filozoficznym jest odpowiedzialność, która dotyczy zarówno samej miłości - tego, czy jest ona właściwa i adekwatnie wyrażana - jak i osób, do których jest skierowana. Kochając, jesteśmy odpowiedzialni za kochane osoby we wszystkich aspektach ich bytu ${ }^{5}$. Adam wyczuwał i coraz bardziej uwewnętrzniał to poczucie odpowiedzialności za drugich, za bezdomnych z ogrzewalni miejskiej, dlatego szukał sposobów zaradzenia ich biedzie: najpierw przez ofiarowywanie im odzieży i jedzenia, później przez prowadzenie regularnej kwesty, a ostatecznie przez dzielenie ich losu.

Innym motywem, któremu można przypisać filozoficzny odpowiednik, jest pojawiający się w scenie rozmowy między Maksem a Stanisławem, do której dołącza Pani Helena i Lucjan, temat „człowieka wymiennego" i „człowieka niewymiennego” $(112-114)^{6}$. W tym rozróżnieniu najbardziej uderza dychotomia istniejąca w człowieku, którą na terenie filozofii można ująć jako podmiotowość i przedmiotowość; także w jakiś sposób chodzi tu o samoświadomość oraz świadomość otaczającej rzeczywistości. Generalnie istniejąca w człowieku dychotomia w swej istocie stanowi podstawę analiz i wyjaśniania rzeczywistości człowieka. Należy stwierdzić, że na tej zasadzie oparte jest główne dzieło filozoficzne Wojtyły Osoba i czyn, gdzie rozróżnienie na to, co człowiek czyni (czyn), oraz na to, co w człowieku się dzieje (uczynnienie), służy do wydobycia fenomenu bycia osobą. Podobnie jest w przypadku samostanowienia i leżących u jego fundamentu struktur samo-panowania i samo-posiadania. Wojtyła twierdzi, że człowiek zarówno sam posiada siebie, jak i jest posiadany przez siebie, a także, że sam sobie panuje, jak również jest tym, nad kim panowanie to jest sprawowane.

\footnotetext{
${ }^{4}$ Wyraźnie widać to w końcowej scenie spowiedzi Adama.

${ }^{5} \mathrm{Na}$ ten aspekt dramatu Wojtyły zwrócił uwagę o. Zdzisław J. Kijas (Kijas 195).

${ }^{6} \mathrm{Na}$ ten motyw w dramacie zwracają uwagę różni komentatorzy (Kijas 191; Kurnik 390; Kaczmarek, „Przeniknąć człowieka” 486).
} 
Człowiek, żyjąc i działając w różnych wspólnotach, może się odnaleźć poprzez uczestniczenie w dobru wspólnym ${ }^{7}$, nawiązując relacje z innymi ludźmi, a zwłaszcza relacje typu ,ja” - „ty”, może uczestniczyć w człowieczeństwie drugiego człowieka. Podstawą zaistnienia takiej relacji oraz tego typu uczestnictwa jest uświadomienie sobie, że drugi człowiek jest również osobą, podobną do mnie, że jest, tak jak ja, stanowiącym o sobie podmiotem czy też - innym ,ja”. Bez tej świadomości, bez odczytania tego podobieństwa, nie będzie możliwe zaistnienie uczestnictwa w człowieczeństwie drugiego człowieka. W dramacie Wojtyły identyfikacja podobieństwa drugiego człowieka przedstawiona została w scenie, w której Adam, prowadząc wewnętrzny spór, spotyka pijanego nędzarza bezradnie trzymającego się ulicznej latarni. Właśnie w nim dostrzega, jak mówi: „Obraz i podobieństwo” (141).

\section{PRZED SKLEPEM JUBILERA - DRAMAT O MIŁOŚCI I MAŁŻEŃSTWIE}

Współgranie myśli filozoficznej i twórczości dramaturgicznej najbardziej jest uchwytne na przykładzie studium Miłość i odpowiedzialność oraz utworu Przed sklepem jubilera - wydanych w tym samym roku (1960) dzieł traktujących o miłości i małżeństwie. W dramacie Przed sklepem jubilera jest niezmiernie dużo wątków, których z powodu ograniczonych ram artykułu nie jesteśmy w stanie omówić, dlatego skupimy się tylko na tych najważniejszych, które wypływają również z filozofii Karola Wojtyły.

Głównym motywem dramatu - jak to stwierdziliśmy - jest miłość między dwojgiem ludzi, między kobietą a mężczyzną. Wojtyła podkreśla, że miłości nie należy utożsamiać z uczuciem, emocjami, zachwytem czy zmysłowością, że błąd ten popełniany jest przez wielu ludzi, którzy mniemają, iż właśnie w tej formie miłość się wyczerpuje. Wojtyła przekonuje, że miłość oparta tylko na uczuciu w którymś momencie życia człowieka wyczerpuje się - co nastąpiło w przypadku małżeństwa Anny i Stefana - a także z tego względu, że człowiek w jakiś sposób ten rodzaj miłości przekracza (205). Gdy bowiem opadnie namiętność i skończy się „absolut uczucia” (185), nie może pozostać pustka, „nie może pozostać nic” - istota miłości musi być zatem inna (206).

W dramacie istotę miłości odkrywamy stopniowo. Poznając pierwszą parę - Teresę i Andrzeja - nie mamy „typowego” obrazu miłości, ukazującego ją jako swego rodzaju uniesienie, uczucie, obezwładniającą siłę, która w jakiś sposób zniewala

\footnotetext{
${ }^{7} \mathrm{~W}$ dramacie za takie dobro uznawana jest sztuka, o czym dowiadujemy się z wypowiedzi Pani Heleny (113).
} 
człowieka zakochanego, nie pozwalając mu myśleć o niczym innym, jak tylko o ukochanej osobie. W przypadku tej pary było inaczej. Aspekt uniesienia uczuciowego i emocjonalnego na początku był wytłumiony (aby rozwinąć się po jakimś czasie). Andrzej próbował ze swojej świadomości usunąc Teresę, robił wszystko, aby o niej nie myśleć, nie zajmować się nią. Unikał jej, szukał towarzystwa innych dziewcząt. Jednak po pewnym czasie stwierdził, że pomimo jego wysiłków Teresa w jakiś sposób jest w nim obecna, a ostatecznie uświadomił sobie, że ją kocha (185).

Andrzej i Teresa dojrzewają do miłości, stopniowo wyzwalając się z ,absolutu uczucia”. Jest to proces, który prowadzi do coraz pełniejszego zjednoczenia myśli i uczuć oraz do coraz pełniejszej wzajemnej akceptacji i afirmacji. Bohaterowie uświadamiają sobie, że są dla siebie nawzajem darem, który można było łatwo utracić, nie dostrzegając drugiej osoby.

Jaka jest ich miłość? Jest to miłość wyzwolona z dyktatu uczucia i zmysłowości, ale bynajmniej ich niepozbawiona. Zajmują one w ich miłości właściwe miejsce. Jest to także miłość świadoma wzajemnego obdarowania się sobą, a także angażująca w całości, czyli na wszystkich poziomach ich życia. Miłość nie stanowi wycinka czy części w ich życiu, ale przenika je w całości. W dramacie Wojtyły jest to pokazane w scenie przed witryną sklepu. Teresa zatrzymała się przed nią, ponieważ chciała kupić buty. Można powiedzieć, że to rzecz jak najbardziej banalna, nic szczególnego, „proza życia”. A jednak w motywacji, która nią kieruje, ujawnia się „totalność” miłości Teresy do Andrzeja, ponieważ chce ona dokonać zakupu niejako z myślą o nim (189). Podobnie jest w przypadku Andrzeja, który - cokolwiek robi - pragnie sprawić przyjemność Teresie i przypodobać się jej (190). Okazuje się więc, że nawet w prozaicznych i drobnych, można powiedzieć w błahych, rzeczach ujawnia się miłość ${ }^{8}$.

Miłość pełna, właściwa, czyli nieskupiająca się tylko na uczuciach i doznaniach zmysłowych, miłość, do której osoba dojrzewa, a osiągnąwszy dojrzałość osobową, pielęgnuje, wreszcie miłość przeżywana jako wzajemne obdarowywanie się to ujęta w kategoriach filozoficznych - miłość oblubieńcza. Aby mogła ona osiągnąć pełnię w związku mężczyzny i kobiety, a więc aby mogła się stać całkowitym darem z siebie, również darem ze swojego ciała musi - według Wojtyły - przybrać formę sakramentu. Poprzez sakrament małżeństwa kochające się osoby „legalizują” swoją miłość wobec Boga oraz społeczności, w której żyją. Dzięki sakramentowi społeczność akceptuje miłość i związek dwojga ludzi oraz zapewnia możliwość trwania i rozwoju tej miłości i powstałej między nimi wspólnoty. Sakrament małżeństwa

\footnotetext{
${ }^{8}$ Rocco Buttiglione pisze, że miłość zawiera w sobie również wymiar ekonomiczny, ponieważ kochający się małżonkowie - aby normalnie funkcjonować - muszą gdzieś mieszkać, pracować i troszczyć się o różne rzeczy materialne (Buttiglione 356).
} 
jest również gwarancją nieprzerwanego trwania ślubowanej miłości oraz nierozerwalności powstałego związku. Wyraża on również (w formie przysięgi małżeńskiej) i zabezpiecza dobro wspólne małżonków, a także odzwierciedla pewną obiektywną rzeczywistość, obiektywny porządek miłości.

Zagadnienie sakramentalności małżeństwa w omawianym dramacie Wojtyły pojawia się w scenach, które mają miejsce w sklepie jubilera lub przed witryną tego sklepu. Symbolem sakramentalności małżeństwa są obrączki - wybierane i przymierzane. Postać starego jubilera w analizach literackich sprawia pewną trudność i nie jest jednoznacznie interpretowana (Dybciak, Karol Wojtyła a literatura 99, Taborski, Dramaturgia wnętrza 65). Wydaje się jednak, że postać tę można odczytać jako symbol samego Boga. Nie oznacza to, że inna interpretacja tej postaci, na przykład jako Kościoła, jest błędna. Kościół jednak występuje raczej w roli świadka, który potwierdza zawarcie ślubu, aniżeli tego, kto tego ślubu faktycznie udziela. Ślubu bowiem udzielają sobie nawzajem sami narzeczeni, a czynią to wobec samego Boga.

Jeśli narzeczeni udzielają sobie nawzajem ślubu i dzieje się to wobec Boga, to niebezpodstawne wydaje się odczytanie postaci Jubilera jako samego Boga (Taborski, Karola Wojtyly dramaturgia wnętrza 66). Wskazują na to określenia obecne w scenie wizyty Andrzeja i Teresy, gdy Jubiler przyglądał się im bardzo wnikliwie, patrzył głęboko w oczy, jakby prześwietlał całego człowieka i jego przyszłość (197). Moc „prześwietlania” człowieka i - w jakimś sensie - zaglądania w jego przyszłość, w jego dalszy los ma tylko Bóg - Kościół takiej mocy nie posiada. Podobnie można zinterpretować scenę, gdy Anna, uznając, że jej miłość do męża (i jego do niej) wygasła, chce sprzedać swoją obrączkę. Jubiler kładzie kilkakrotnie obrączkę na wagę, a kiedy przyrząd nic nie wskazuje, stwierdza, że nie może tej obrączki kupić, ponieważ mąż Anny zapewne żyje (202). Jubiler mówi jej, że jego waga ma tę szczególną właściwość, że „nie odmierza metalu, lecz cały byt człowieka i jego los” (202). Taka władza nie przysługuje Kościołowi, lecz wyłącznie Bogu, który „zna człowieka” i może sprawiedliwie osądzić całe jego życie.

Ciekawe jest również ukazanie przez Wojtyłę postaci Jubilera jako wytwórcy i sprzedawcy obrączek, które symbolizują zawarte małżeństwo. Nie jest przecież istotny materiał, z jakiego obrączki są wykonane, jaką mają próbę czy też jak wyglądają i jak prezentują się na palcu, lecz to, co symbolizują - są znakiem przymierza zawartego między kobietą a mężczyzną. Jest to przymierze ich dalszego wspólnego życia bez względu na koleje losu, a więc przymierze miłości i wierności zawarte „na zawsze". Wyraża ono prawdę, że ich miłość i ich związek może zakończyć wyłącznie śmierć któregoś z małżonków. Scena w sklepie Jubilera, gdy Anna chce sprzedać swoją obrączkę, mówi o tym, że małżeństwo jest nierozerwalne, póki małżonkowie żyją, że małżeństwa nie można przerwać, nie można uchylić raz zawartego przymierza. Nie można rozbić powstałej raz jedności, przejawiającej się we wspólnym 
życiu - „wspólnocie stołu i łoża” - ale również w innym znaku tej jedności, jakim są dzieci (215).

W tym miejscu naszkicujemy przypadek miłości trzeciej pary, którą stanowią Monika i Krzysztof. Ich związek jest pewną syntezą (przynajmniej częściową) miłości i małżeństwa ich rodziców, ale także ich własnych wyborów. Nie bez znaczenia jest to, jakimi ludźmi są ich rodzice, że ich postawa na długo pozostaje w dzieciach i na nie oddziałuje. W przypadku Moniki wpływ jej rodziców był negatywny, nie otrzymała ona dobrego wzoru ani miłości, ani małżeństwa. Krzysztof natomiast, pomimo że jego ojciec nie żył, otrzymał pozytywny przekaz tego, jak powinny wyglądać miłość i małżeństwo. Z dramatu Wojtyły wynika, że w związku Moniki i Krzysztofa to właśnie on nadaje ich uczuciu właściwy kształt. Przede wszystkim Krzysztof ma właściwe rozpoznanie rzeczywistości. Jest świadomy tego, że wskutek braku ojca nie ma fundamentu, na którym mógłby się oprzeć w budowaniu związku z Moniką. Jest jednak świadomy i tego, że pomimo owego braku może budować udany związek, szczęśliwie kochać. Trzeźwo patrzy na Monikę oraz jej rodziców, wie, że - jak powiedział - musi zdobywać ją dla niej samej oraz dla jej rodziców i że jej rodzice go nie lubią. A jednak pomimo nieprzychylności rodziców Moniki oraz oporu stawianego przez nią, nie rezygnuje z miłości, nie poddaje się, podejmuje trud jej budowania. Kieruje nim bowiem przeświadczenie, że prawdziwa miłość jest głębsza niż wzruszenie, emocjonalne pobudzenie czy uczucie. Według niego, ważne jest to, co pozostaje po opadnięciu wzruszeń i emocji związanych z zakochaniem (218). Uważa, że prawdziwa miłość wymaga poświęcenia dla niej całego człowieka, porzucenia wszystkiego, co jej nie służy, co nie służy kochanej osobie. Mamy tutaj do czynienia z przekonaniem o „totalności” miłości, o tym, że należy jej poświęcić wszystko, że człowiek powinien całkowicie poświęcić się dla drugiego (kochanego) człowieka (217). Krzysztof mówi, że miłość jest ciągłym wyzwaniem rzucanym przez Boga człowiekowi. Każdego dnia trzeba na nowo odkrywać prawdę zwyczajnych rzeczy i spraw, przeżywać miłość jako relację i proces (218). Jest to więc miłość głębsza niż przemijające wzruszenie, sięgająca istoty człowieka, objawiająca się w codziennym życiu, codziennych obowiązkach spełnianych z miłością i z powodu miłości, przez miłość przemienianych i wynoszonych na wyższy poziom - na poziom właściwy osobie. Tak rozumianą miłość można nazwać miłością oblubieńczą.

Interesujące uwagi na temat miłości oblubieńczej zawarte są w rozmowie Anny z Adamem - przyjacielem Teresy i Andrzeja, duchowym opiekunem Krzysztofa. Według Adama, miłość jest czymś istotnym, wykraczającym poza przemijające uczucia i doznania, stanowi syntezę istnienia dwojga ludzi (205). Miłość jest ciągłym rozwojem, nie wyczerpuje się, lecz trwa tak długo, jak długo żyją osoby się kochające. Jeśli jednak miłość wygasa, to dzieje się tak dlatego, że była zbyt płytka (225), czyli inaczej mówiąc: nieprawdziwa. 
Pozytywne i optymistyczne przesłanie utworu Wojtyły zawarte jest w scenie ślubu Moniki i Krzysztofa, a polega na tym, że każdy człowiek ma możliwość stanowienia o sobie, decydowania o tym, kim chce być oraz co chce robić. Samostanowienie pokonuje zewnętrzne przeszkody czy uwarunkowania. W omawianym utworze w przypadku Moniki i Krzysztofa jest to bagaż ich doświadczeń i wzorów wyniesionych z domów. Jednak te doświadczenia nie mają determinującej mocy. Negatywne wzorce nie muszą być ani utrwalane, ani powielane. Monika i Krzysztof mogą odkryć siebie nawzajem i pokochać miłością prawdziwą, do której są powołani (podobnie jak powołany jest do niej każdy człowiek ${ }^{9}$ ). Mogą na nowo tworzyć siebie, swoją miłość i małżeństwo. Pomimo negatywnych wzorców, mogą spełnić się osobowo, ponieważ mogą stanowić o sobie - i tak też Monika i Krzysztof czynią.

\section{PROMIENIOWANIE OJCOSTWA - MISTERIUM MIŁOŚCI I OSOBOWEGO SPEŁNIENIA MĘŻCZYZNY}

Na początku naszej analizy kolejnego dramatu Wojtyły pod kątem zawartych w nim wątków filozoficznych należy stwierdzić - na co zwraca także uwagę Zbigniew Władysław Solski (340) - że Promieniowanie ojcostwa, podobnie jak wcześniej omówione utwory dramatyczne, jest „próbą przeniknięcia człowieka”. Pod tym względem utwory te stanowią pewną całość. W obecnie analizowanym dramacie owo „przenikanie człowieka” odbywa się w aspekcie jego ojcostwa (na co wskazuje sam tytuł), jak również w aspekcie macierzyństwa i dziecięctwa. Ojcostwo jest bowiem możliwe wyłącznie w połączeniu czy zespoleniu z macierzyństwem kobiety oraz dziecięctwem zrodzonych nowych osób. Bez tych dopełniających aspektów relacji między osobami mężczyzny i kobiety, którzy wraz z poczęciem dziecka - nowej osoby stają się ojcem i matką, nie można byłoby w sposób pełny mówić o ojcostwie mężczyzny.

Głównym bohaterem dramatu Wojtyły jest postać o imieniu Adam. Należy zwrócić uwagę, że Autor umieścił postać o tym imieniu we wszystkich swoich trzech dramatach (Karoń-Ostrowska 122; Sawicki 454-455). W utworze Brat naszego Boga jest to Brat Starszy. Chociaż sztuka nawiązuje do postaci historycznej - Adama Chmielowskiego, późniejszego brata Alberta - to we wstępie Wojtyła napisał, że przesłania utworu nie należy łączyć jedynie z konkretną osobą, która na przełomie dziewiętnastego i dwudziestego wieku żyła i działała w Krakowie. W dramacie Przed

\footnotetext{
${ }^{9}$ Odzwierciedleniem tego powołania są słowa z Konstytucji duszpasterskiej o Kościele w świecie współczesnym Gaudium et spes nr 24: „Człowiek nie może inaczej siebie odnaleźć, jak tylko poprzez bezinteresowny dar z samego siebie".
} 
sklepem jubilera występuje postać nieznajomego, który jest zarazem przyjacielem Teresy i jej syna Krzysztofa, jak i osobą wkraczającą w życie Anny, która przeżywa kryzys małżeński. To dzięki Adamowi nie dochodzi do rozpadu jej małżeństwa.

W dramacie Przed sklepem jubilera pojawia się określenie Adama jako kogoś, kto stanowi wspólny mianownik wszystkich ludzi. Podobne sformułowanie znajdujemy również w Promieniowaniu ojcostwa, gdy Adam w scenie, w której obserwuje ludzi wychodzących z huty i zmierzających do swoich spraw i domów, stwierdza, że stanowi on wspólny mianownik ich dziejów. Dlatego uzasadnione wydaje się stwierdzenie, że Adam to uosobienie czy odzwierciedlenie człowieczeństwa, które jest wspólne wszystkim ludziom, a także doświadczenia ich zróżnicowanych losów składających się na wspólne dziedzictwo ludzkości.

Imię „Adam”, które nosi bohater omawianego utworu, stanowi zatem pewien symbol tego, co jest wspólne wszystkim ludziom, czyli człowieczeństwa. W stwierdzeniu tym można dopatrywać się motywu uczestnictwa w tym, co podstawowe we wspólnocie bytu i losu, w tworzonej przez wszystkich ludzi wspólnocie w człowieczeństwie. Pomimo uczestnictwa we wspólnocie, której podstawą jest człowieczeństwo, Adam nie potrafi się w niej odnaleźć. W scenie drugiej, prowadząc dialog z Bogiem, stwierdza, że jego drogą jest samotność. Jak dochodzi do tego wniosku? Pragnąc upodobnić się do Boga, Adam błędnie rozpoznaje Jego istotę. Stwierdza, że Bóg jest samowystarczalny: ponieważ stworzył On wszystko, to wszystko do Niego należy, nic więc nie może należeć do Adama, nic nie może być jego „własne”. Adamowi wydaje się również, że Bóg jest sam - i dlatego on również pozostanie sam (230). Odczytanie „,istoty” Boga, jakiego dokonał Adam, jest jednak fałszywe (Schmitz 126; Zarębianka 329). Bóg bowiem nie jest samotny, ponieważ cechuje Go komunia Osób Boskich: Ojca, Syna i Ducha Świętego, czyli wzajemne obdarowywanie się miłością przez Osoby Boskie. Miłość ta manifestuje się w akcie stworzenia świata i człowieka, jako bezinteresowny i wolny dar Boga. To właśnie komunia Trójcy Świętej oraz miłość jako dar stanowią wzór dla człowieka, który tworzy różnego rodzaju wspólnoty - w tym wspólnotę najbardziej podstawową, jaką jest rodzina. Należy dodać, że uczestnicząc w tych wspólnotach, człowiek realizuje się jako osoba.

Adam, kierując się fałszywym obrazem Boga, staje się samotny. Co więcej, wybiera samotność, aby stać się podobnym do Boga, ale przez swój wybór zamyka się na innych. To zamknięcie się na innych Wojtyła przedstawia w swojej filozofii jako jedną z postaci alienacji. Adam, chociaż uznał siebie za „mianownik wszystkich ludzi”, wybierając samotność, przekreślił możliwość uczestniczenia we wspólnym losie innych ludzi, a także odebrał sobie możliwość realizowania siebie jako osoby przez wspólne z nimi działanie. Pozostaje poza wszelką wspólnotą, zamyka się w sobie. Jest to droga, która w konsekwencji może prowadzić do zniszczenia go jako osoby. 
W wyniku dalszych rozważań Adam odkrywa, że samotność nie stanowi podstawy jego bytowania i realizacji jako człowieka. Stwierdza, że samotność zaczyna się dopiero w pewnym momencie, w jakimś punkcie, i o wiele głębiej odnajduje w swoim bycie szczelinę, przez którą wchodzi Bóg (232). Można powiedzieć, że szczelina ta prowadzi do samej podstawy bytu Adama, a więc i wszystkich ludzi. Podstawą tą jest miłość ${ }^{10}$ : miłość mężczyzny do kobiety, a w aspekcie ojcostwa miłość do poczętego i wydanego na świat dziecka. Doskonale oddają to słowa dramatu: „Chcesz, abym miłował. Trafiasz do mnie przez dziecko, przez maleńką córeczkę lub synka - i mój opór słabnie. Nie pozostaje nic z tej samotności, którą usiłuję przeciwstawić się Tobie" (232).

Warto zwrócić uwagę na jeszcze jedną - przedstawioną w dramacie Wojtyły - przyczynę lęku Adama, wiodącą go na ścieżki samotności. Boi się on miłości, a jeszcze bardziej odpowiedzialności - tak za samą miłość, jak i za kochane osoby. Miłość bowiem, aby była miłością prawdziwą, domaga się odpowiedzialności za samego siebie i za kochane osoby. Nie może być ślepa, kierować się namiętnością bądź chwilowym zauroczeniem, lecz powinna sięgać głębiej. Powinna być kształtowana przez człowieka jako osobę, a jej podstawą powinien być świadomy i wolny wybór zarówno osoby, jak i miłości do niej. Powiązanie miłości - a zwłaszcza miłości między mężczyzną a kobietą - z odpowiedzialnością zostało przez Wojtyłę opracowane teoretycznie w przywołanym już wcześniej studium Miłość i odpowiedzialność.

Część pierwszą dramatu kończy scena piąta, zatytułowana „Matka”. Oprócz Adama pojawia się w niej kobieta, która jest właśnie matką. Stwierdza ona między innymi, że dziecko wskazuje na miłość, dzięki której jest ono na świecie, oraz na osoby obdarowujące się nawzajem tą miłością, której jest owocem. Dziecko to zatem znak miłości oblubieńczej małżonków, którzy dzięki dziecku stają się rodzicami matką i ojcem. Dziecko jest owocem ich miłości, ich wzajemnego obdarowania się sobą, także w wymiarze cielesnym. Będąc cielesnym znakiem ich wzajemnej miłości, jest ono także darem dla rodziców. Rodzice pragną dziecka dla niego samego.

Matka wypowiada również inną ważną myśl: ,,aby urodzić, trzeba bardziej jeszcze wybrać" (234). Jest to - jak się wydaje - główna myśl tego dramatu. Wskazuje ona, że aby osiągnąć pełnię ojcostwa, jak również macierzyństwa i dziecięctwa, nie wystarczą zewnętrzne relacje i zależności: muszą one zostać dopełnione - czy też

${ }^{10}$ Wojtyła często przywoływał myśl, która zawarta jest w nr. 24 Konstytucji duszpasterskiej o Kościele w świecie współczesnym Gaudium et spes (jak wiadomo, brał on udział w jej redagowaniu (Skrzypczak)), że w stosunku do innych ludzi człowiek nie może się odnaleźć jako osoba inaczej, jak tylko przez bezinteresowny dar z samego siebie. 
wypełnione - osobową treścią. Treść ta pochodzi z wnętrza i jest jego podmiotową realizacją i spełnieniem ${ }^{11}$.

Należy dodać, że wybór, o którym mówi Matka, stanowi podstawę miłości. Mężczyzna wybiera w sobie miłość do kobiety, która staje się jego żoną, a później matką, wybiera miłość do dziecka, a osoby te wybierają w sobie miłość do mężczyzny męża i ojca.

W drugiej części dramatu Wojtyła przedstawia konkretyzację budzenia się i dojrzewania ojcostwa Adama oraz jego miłości do Moniki, która z czasem staje się jego córką. Wojtyła przedstawia wewnętrzną ewolucję, jaka dokonuje się zarówno w Adamie, jak i w Monice. Swoistą kulminację stanowi scena wędrówki przez las, a następnie spotkanie żmii, która zagroziła dziecku. Adam po raz pierwszy przeżywa wówczas niepokój o Monikę i ochrania ją przed ukąszeniem. Należy podkreślić, że według filozoficznej koncepcji Wojtyły przeżycie odgrywa istotną rolę w konstytuowaniu się podmiotu jako osoby. Można zatem powiedzieć, że wraz z pojawieniem się przeżycia Adam zaczyna konstytuować się jako ojciec, a jednocześnie zaczyna się również konstytuować jego miłość do dziecka.

Monika - jak zdaje się wynikać z tekstu utworu - być może już wcześniej „,zrodziła" w sobie ojca w osobie Adama. Z tekstu można wyczytać, że jej biologiczny ojciec jest w jej życiu nieobecny od bardzo dawna, ponieważ dziewczynka go nie pamięta ${ }^{12}$. Adam staje się więc jej ojcem przybranym. Zanim się to jednak dokonało, Monika stopniowo wchodziła w życie Adama. Przeżycie związane ze żmiją także dla Moniki jest w jakiś sposób przełomowe: uważa ona, że Adam uratował jej życie, a przez to niejako darował jej je na nowo.

Na kanwie budzenia się i dojrzewania do ojcostwa równolegle rozwija się miłość. Ojcostwo to nie tylko relacja do dziecka i matki, to również miłość. Bez miłości ojcostwo nie osiągnęłoby swojej pełni. Można powiedzieć, że zarówno w myśli filozoficznej, jak i twórczości literackiej jednym z najważniejszych tematów jest właśnie miłość. Tak jest i w przypadku omawianego dramatu, którego tematem jest ojcostwo.

Jedną z najważniejszych myśli tego utworu, którą można odnieść do ogólnego pojmowania miłości, stanowi uznanie miłości za sprawę wyboru. Wojtyła pisze: „Rodzimy się [...] przez wybór - rodzimy się wówczas od wewnątrz, / i nie rodzimy się naraz, lecz jakby cząstka po cząstce... / Nie tyle się wówczas rodzimy, ile stajemy" (247). Wojtyła zdaje się mówić, że miłość jest procesem, czymś dynamicznym, czymś, co nas kształtuje. Istota miłości wyraża się w potwierdzaniu przez całe życie

${ }^{11}$ Należy zwrócić uwagę, że biologiczne ojcostwo jest jedynie podstawą do tego, aby ojcostwo uzyskało swoją pełnię przez jego świadome przyjęcie i potwierdzanie w swoim życiu.

${ }^{12}$ Chociaż istnieją różne interpretacje, to przychylam się do stanowiska, że tekst dramatu jednoznacznie wskazuje, iż Adam nie jest biologicznym ojcem Moniki. 
naszego wyboru kochania danej osoby. Dlatego - ze względu na samą swoją naturę - miłość nie może się skończyć, nie można z niej zrezygnować ani się jej wyrzec. Wymaga ona stałego - by nie powiedzieć - ustawicznego potwierdzania jej swoim życiem. Nie chodzi tutaj o heroiczne czyny, lecz o zwyczajne, drobne akty - troskę, opiekę, uśmiech, zainteresowanie.

Miłość osiąga swoją pełnię, gdy dokonujemy całkowitego daru z samego siebie na rzecz innej osoby. Dar ten najlepiej sprawdza się i objawia właśnie w codzienności, w „szarości dnia”. Dokonywane każdego dnia potwierdzanie wyboru miłości jest właśnie codziennym składaniem daru z samego siebie. Doskonałość takiej miłości polega na tym, że codzienne obowiązki, drobne prace czy wręcz błahostki stają się darami, które ofiarujemy kochanym osobom. Jej wielkość polega również na tym, że stwarza możliwości i sposobność do tego, aby nie zatrzymywać się jedynie na poziomie obowiązku, lecz z obowiązku uczynić dar. Poprzez dar afirmujemy osobę, do której go adresujemy. Składamy dar komuś, kogo uznajemy za godnego naszego daru - to również jest sprawą wyboru. Wybrawszy zaś, swoimi czynami ustawicznie potwierdzamy godność tej osoby.

Wojtyła, przedstawiając budzenie się miłości ojcowskiej Adama do Moniki, rysuje ich wcześniejszą relację w taki sposób, by uwydatnić rolę i wagę osobowego, a więc podmiotowego wybrania czy też przyjęcia ojcostwa. Ojcostwo, podobnie jak miłość, jest domeną wolności, której podstawą jest samostanowienie. Mężczyzna może w pełni przyjąć na siebie ojcostwo i kształtować je w miłości tylko wtedy, gdy jest całkowicie wolny i świadomy. Waga wyboru miłości polega również na tym, że inną osobę czynię „moją”, a więc w jakiś sposób „własną” (mowa o tym w scenie zatytułowanej: „Ojciec i dziecko ogarniają się za pośrednictwem słowa «moje»”). Mówiąc „moja żona”, „moje dziecko”, określamy pewną współprzynależność, wspólne bytowanie i dzielenie życia, a także tworzenie jedności osób, które Wojtyła określa mianem communio personarum. To właśnie na gruncie tej wspólnoty możliwe jest wzajemne obdarowywanie się człowieczeństwem: wzajemne obdarowywanie ojcostwem, macierzyństwem oraz dziecięctwem.

Miłość - o czym już mówiliśmy - jest pewnym procesem, jest dynamiczna. Swoją żywotność czerpie z codziennych aktów, które ją potwierdzają i rozwijają. W aktach pozostajemy wolni; w innym wypadku utraciłyby one swoją moc oraz utraciłyby swój właściwy sens - przestałyby oznaczać trwanie miłości, umacnianie się w niej. Poza tym mogę ofiarować komuś siebie w miłości (a więc także swoje akty miłości) tylko wtedy, gdy siebie samego posiadam, czyli gdy sam o sobie stanowię. Samostanowienie jest najwyższym przejawem wolności człowieka jako osoby. Dlatego kochając, sam stanowię o sobie, jestem w pełni wolny jako osoba. Należy zatem stwierdzić, że miłość ani nie ogranicza, ani nie znosi wolności osoby, lecz umożliwia pełną jej realizację. 
Podsumowując powyższe analizy można powiedzieć, że głównym tematem zajmującym Wojtyłę tak w twórczości dramaturgicznej, jak i w prowadzonych badaniach filozoficznych jest człowiek w różnych wymiarach jego życia, a zwłaszcza w wymiarze osobowego spełnienia, osiągającego swoją pełnię w miłości oblubieńczej. Człowiek rozumiany jako osoba, czyli byt rozumny i wolny, posiadający zdolność do wchodzenia w relacje międzyosobowe, dzięki którym może osiągnąć pełnię swojego osobowego bytowania. Jest to zatem ujęcie z perspektywy personalistycznej, która w badaniach naukowych Wojtyły przyjmuje postać antropologii personalistycznej, a jej tezy w utworach dramatycznych poddawane są badaniu wykraczającemu poza ramy dostępne filozofii. Metodą badawczą jest doświadczenie, w tym doświadczenie moralne, w dramatach przejawiające się w próbach „przeniknięcia człowieka”. Artykuł, zarówno ze względu na ograniczoną objętość, jak i z uwagi na przyjęty obszar badawczy, tylko w sposób ogólny i raczej sygnalizujący ukazał pewne wspólne tematy pojawiające się w dramatach i myśli filozoficznej Wojtyły, zaś sama tematyka wymaga dalszego opracowania.

\section{BIBLIOGRAFIA}

Buttiglione, Rocco. Myśl Karola Wojtyty. Towarzystwo Naukowe KUL, 1996.

Dybciak, Krzysztof. „Rewolucja czy wybór większej wolności? Antropologiczno-społeczne podstawy Brata naszego Boga". Ethos, nr 2-3(6-7), 1989, ss. 43-52.

Dybciak, Krzysztof. Karol Wojtyła a literatura. Biblos, 1991.

Heck, Dorota. „Pojęcie sprawiedliwości w Bracie naszego Boga a liberalna teoria sprawiedliwości Johna Rawlsa”. Karol Wojtyła - poeta, red. Jacek Głażewski i Witold Sadowski, Wydawnictwa Uniwersytetu Warszawskiego, 2006, ss. 217-222.

Kaczmarek, Wojciech. „Od doświadczenia człowieka do miłości osoby. Osoba i relacje osobowe w twórczości literackiej Karola Wojtyły - Jana Pawła II”. Ethos, nr 3(127), 2019, ss. 351-376.

Kaczmarek, Wojciech. „Przeniknąc człowieka. Osoba i słowo w dramaturgii Karola Wojtyły”. Zeszyty Naukowe KUL, t. 47, nr 3, 2004, ss. 31-41.

Krzysztof, Dybciak. Pisarstwo Karola Wojtyly - Jana Pawła II w oczach krytyków i uczonych. Państwowy Instytut Wydawniczy, 2019, ss. 482-493.

Karoń-Ostrowska, Anna. Dramat spotkania. „Promieniowanie ojcostwa” jako pryzmat filozofii Karola Wojtyty. Więź, 2010.

Kijas, Zdzisław J. „Wizja Boga i człowieka w utworach literackich Karola Wojtyły”. Przestrzeń słowa. Twórczość literacka Karola Wojtyły - Jana Pawła II, red. Zofia Zarębianka i Jan Machniak, Wydawnictwo św. Stanisława BM, 2006, ss. 187-196.

Kurnik, Agnieszka. „Odkrywanie świętości. Brat naszego Boga Karola Wojtyły”. Przestrzeń słowa. Twórczość literacka Karola Wojtyły - Jana Pawła II, red. Zofia Zarębianka i Jan Machniak, Wydawnictwo św. Stanisława BM, 2006, ss. 387-395.

Reale, Giovanni. Karol Wojtyła. Pielgrzym Absolutu. Tłum. Małgorzata Gajda, Centrum Myśli Jana Pawła II, 2008.

Sawicki, Stefan. „Trylogia dramatyczna Karola Wojtyły”. Dramat i teatr religijny w Polsce, red. Irena Sławińska i Wojciech Kaczmarek, Towarzystwo Naukowe KUL, 1991, ss. 447-456. 
Schmitz, Kenneth. „Przejście miłości. Promieniowanie ojcostwa Karola Wojtyły”. Communio, nr 1(91), 1996, ss. $125-132$.

Skrzypczak, Robert. Karol Wojtyła na Soborze Watykańskim II. Zbiór wystapień. Centrum Myśli Jana Pawła II, 2011.

Sobór Watykański II. Konstytucja duszpasterska o Kościele w świecie współczesnym Gaudium et spes, 1965.

Solski, Zbigniew W. „Ojcostwo i tożsamość”. Przestrzeń słowa. Twórczość literacka Karola Wojtyly - Jana Pawła II, red. Zofia Zarębianka i Jan Machniak, Wydawnictwo św. Stanisława BM, 2006, ss. $335-358$.

Taborski, Bolesław. Dramaturgia wnętrza. Redakcja Wydawnictw KUL, 1983.

Taborski, Bolesław. Karola Wojtyty dramaturgia wnętrza. Redakcja Wydawnictw KUL, 1989.

Wierzbicki, Alfred M. „Antropologia Karola Wojtyły odczytana w jego poezji”. Ethos, nr 4(76), 2006, ss. 103-113.

Wojtyła, Karol. „Brat naszego Boga”. Karol Wojtyła. Poezje i dramaty. Wybór i układ Marek Skwarnicki i Jerzy Turowicz, Znak, 1979, ss. 109-182.

Wojtyła, Karol. „O miłości oblubieńczej (Na marginesie dyskusji)”. Roczniki Filozoficzne, t. 27, z. 2, 1974, ss. $162-174$.

Wojtyła, Karol. „Osoba i czyn”. Karol Wojtyła. Osoba i czyn oraz inne studia antropologiczne. Towarzystwo Naukowe KUL, 1994, ss. 43-344.

Wojtyła, Karol. „Promieniowanie ojcostwa”. Karol Wojtyła. Poezje i dramaty. Wybór i układ Marek Skwarnicki i Jerzy Turowicz, Znak, 1979, ss. 228-258.

Wojtyła, Karol. „Przed sklepem jubilera”. Karol Wojtyła. Poezje i dramaty. Wybór i układ Marek Skwarnicki i Jerzy Turowicz, Znak, 1979, ss. 183-227.

Wojtyła, Karol. „Rodzicielstwo a communio personarum”. Ateneum Kapłańskie, t. 84, 1975, ss. 17-31.

Wojtyła, Karol. „Rodzina jako communio personarum. Próba interpretacji teologicznej”. Ateneum Kaptańskie, t. 83, 1974, ss. 347-361.

Wojtyła, Karol. Miłość i odpowiedzialność. Towarzystwo Naukowe KUL, 1986.

Zarębianka, Zofia. „Dojrzewanie do śmierci, dojrzewanie do ojcostwa”. Przestrzeń słowa. Twórczość literacka Karola Wojtyly - Jana Pawła II, red. Zofia Zarębianka i Jan Machniak, Wydawnictwo św. Stanisława BM, 2006, ss. 321-333.

\section{WĄTKI FILOZOFICZNE \\ W DRAMATACH KAROLA WOJTYŁY}

\section{Streszczenie}

Celem artykułu jest wskazanie w utworach dramatycznych Karola Wojtyły scen, problemów i tematów, które w jakiejś formie pojawiają się także w prowadzonej przez niego pracy badawczej. Przyjętą metodą badawczą, służącą osiągnięciu tego celu, jest analiza i porównanie utworów dramaturgicznych i prac filozoficznych pod kątem występowania w nich wspólnych tematów, przy jednoczesnym zachowaniu świadomości, że należą one do odrębnych dziedzin i wyrażane są językiem sobie właściwym. Efektem tak podjętego badania jest wskazanie wspólnych dla twórczości dramaturgicznej i myśli filozoficznej tematów oraz problemów, którymi między innymi są: dojrzewanie oraz spełnianie się człowieka jako osoby, a więc jako bytu rozumnego i wolnego, a także otwartego na relacje międzyosobowe i zdolnego do tworzenia wspólnoty; miłość, w różnych jej przejawach, a zwłaszcza miłość oblubieńcza; ogólne nakierowanie poznawcze na człowieka, które dokonywane jest za pomocą szeroko pojętego doświadczenia.

Słowa kluczowe: Karol Wojtyła; osoba; wolność; miłość; wspólnota; doświadczenie 


\section{PHILOSOPHICAL MOTIFS \\ IN THE PLAYS OF KAROL WOJTYŁA}

\section{Sum mary}

The aim of this paper is to identify, in the plays written by Karol Wojtyła, those scenes, problems and themes which are also present, albeit in a different form, in his scholarly output. To achieve this aim, a method of analysis and comparison was adopted: the author looked for common motifs present in Wojtyła's dramas and in his philosophical works, while keeping in mind the differences between these two areas of intellectual activity, and especially their specific language. The result of this research is the discovery of the following themes and problems addressed by Wojtyła, both as a playwright and as a philosopher: human development, maturity, and one's fulfilment as a person, i.e. as a rational and free being open to interpersonal relationships and capable of creating a community; love in its different manifestations, particularly spousal love; and the human being as the general cognitive focus of reflection based on broadly understood experiences.

Keywords: Karol Wojtyła; person; freedom; love; community; experience 